\title{
EDITOR'S CORNER
}

The Harvard Business School and the Newcomen Society of the United States announce a postdoctoral fellowship in business history to support twelve months of residence, study, and research at the Harvard Business School for the academic year 1989-90. The residence period for next year's Fellow will begin on 1 September 1989.

The purpose of this award is to enable scholars who have received their Ph.D. in history, economics, or a related discipline within the past ten years to improve their professional acquaintance with business and economic history, to increase their skills as they relate to this field, and to engage in research that will benefit from the resources of the Harvard Business School and the Boston scholarly community. The successful applicant will be asked to participate in the school's business history course, seminar, and case development activities.

Those interested should request an application form from:

Professor Alfred D. Chandler, Jr.

Baker Library 214

Harvard Business School

Soldiers Field

Boston, MA 02163

Applications for the 1989-90 Newcomen Fellowship must be received no later than 15 March 1989.

Harvard is an equal opportunity, affirmative action employer.

The Harvard Newcomen Fellow for 1988-89 is W. Bernard Carlson, assistant professor of humanities at the University of Virginia. Carlson holds a Ph.D. in the history and sociology of science from the University of Pennsylvania. He has taught at Michigan Technological University and also served as a research associate for the Thomas A. Edison Papers at Rutgers University. Carlson is writing a book entitled Invention, Science, and Business: The Professional Career of Elihu Thomson, 1870-1900, which explores how an individual inventor was able to exercise his creativity and talent within a complex business organization.

We are delighted to report that the 1987 Wadsworth Prize for Business History has been awarded to Steven W. Tolliday, assistant professor of business administration at the Harvard Business School and associate editor of the Business History Review, for his book, Business, Banking, and Politics: The Case of British Steel, 1918-1939 (Harvard University Press, 1987). The prize, awarded by the British Archives Council, is given annually to the best book or article in the field of British business history.

The Economic and Business Historical Society will hold its 14th annual meeting at the Radisson Francis Marion Hotel in Charleston, South Carolina, on 27-29 April 1989. Members and nonmembers are invited to submit papers, to chair or serve as discussants for sessions, and to make program suggestions. The EBHS encourages interdisciplinary scholarship in economic and business his- 
tory, and its international membership includes men and women with interests in economics, history, business, social science, geography, and other disciplines. Program proposals, including a two-page abstract, should be sent to Jack Blicksilver, Department of Economics, Georgia State University, University Plaza, Atlanta, GA 30303.

The Hagley Museum and Library has available a number of fellowships for 1989-90. Advanced Research Fellowships are available at the Center for the History of Business, Technology, and Society for six to twelve months' work, with a maximum stipend of $\$ 27,000$. Applicants must not be degree candidates and must be either American citizens or resident in the United States for the three years preceding the term of fellowship. Dissertation Fellowships are also available. Two regional fellowships of $\$ 12,500$ are offered to doctoral candidates studying at universities in New Jersey, Maryland, eastern Pennsylvania, and the District of Columbia. One residential dissertation fellowship, with a stipend of $\$ 13,500$, will be awarded to an applicant from the United States or abroad; candidates must demonstrate the importance of the Hagley's collections to the dissertation topic. Completed applications for both these programs are due no later than 15 February 1989. Grants-in-aid for short-term research are also available for the calendar year 1989. For additional information, please contact the Executive Administrator, Hagley Museum and Library, P.O. Box 3630, Wilmington, DE 19807; 302-658-2400.

The Society for Historians of the Early American Republic (SHEAR) will hold its annual meeting in Charlottesville, Virginia, on 20-22 July 1989. Younger scholars, local or regional historians, and public historians are especially invited to attend. Inquiries about membership in SHEAR should be addressed to James H. Broussard, Lebanon Valley College, Annville, PA 17003.

The Hagley Program in the History of Industrial America, a joint program of the Hagley Museum and Library and the University of Delaware's Department of History, announces the availability of fellowships for graduate study beginning in the fall semester of 1989. The program offers a two- or four-year course of study leading to an MA or Ph.D. degree for students interested in careers as professionals in museum and historical agencies or as college teachers. Students take a broad range of courses in business, economic, labor, social, and technological history and can concentrate their studies in any of these fields of history. The Hagley Museum and Library provides students with unique opportunities to do primary research and gain archival experience in manuscripts, imprints, and pictorial collections and to experience museum work firsthand. Hagley Fellowships include tuition and a yearly stipend of $\$ 7,785$ for MA candidates and $\$ 8,625$ for Ph.D. candidates. Applications for Hagley Fellowships can be obtained from the Associate Coordinator, Hagley Graduate Program, Department of History, University of Delaware, Newark, DE 19716. For further information, call 302-451-2371.

The Society for the History of Technology (SHOT) will hold its annual meeting at the Hyatt Regency Hotel in Sacramento, California, during 12-15 October 
1989. The program committee has issued a call for papers in all areas of the history of technology, although contributions that emphasize gender, the Third World, the West as a region, pre-twentieth century topics, and cross-disciplinary perspectives are particularly encouraged. Proposals are also invited for presentations in alternative formats, such as audio-visual or photographic materials and computer demonstrations. The deadline for receipt of proposals is 1 April 1989. Paper proposers should provide a 150 -word abstract and a c.v.; session proposals should include the theme of the session, an abstract of each paper, and a c.v. for each participant, including chair and commentator. Please send four copies of each proposal to Thomas J. Misa, Department of Humanities, Illinois Institute of Technology, Chicago, IL 60616. The program chair can be reached at 312-567-3465 or by electronic mail at HUMMISA@IITVAX.Bitnet.

The annual luncheon of the American Urban History Association will be held on Saturday, 8 April 1989 at noon in the Adam's Mark Hotel in St. Louis, Missouri, in conjunction with the Organization of American Historians meeting. Graeme Davison, of Harvard University and Monash University, will present a paper on "Australia: The First Suburban Nation?" Tickets will be available as part of the OAH pre-registration package or at the OAH registration desk. For additional information, contact Blaine Brownell, College of Social and Behavioral Sciences, University of Alabama, Birmingham, AL 35294, 205-934-5643, or Mark Rose, Program in Science, Technology, and Society, Michigan Technological University, Houghton, MI 49931, 906-487-2115.

The Department of History at the Ohio State University announces the establishment of a graduate fellowship in business history, to begin in fall 1989. Two years of fellowship support and three years of support through a position as a teaching associate will be provided to an incoming student who intends to pursue a Ph.D. in the field of business history. Interested applicants should contact K. Austin Kerr, Department of History, The Ohio State University, 106 Dulles Hall, 230 West 17 Avenue, Columbus, OH 43210.

The Hagley Museum and Library has opened the records of the Pennsylvania Railroad for research. This 1,600-linear foot collection includes minutes, board files, and other corporate records of the PRR and nearly four hundred of its predecessor and subsidiary firms. The records of the Pennsylvania Railroad constitute a major resource for the study of railroad corporate strategy, technology, labor relations, and operating practices. For further information, contact the Manuscripts and Archives Department of the Hagley Museum and Library, P.O. Box 3630, Wilmington, DE 19807, 302-658-2400, ext. 330. 